\title{
PHYSIOLOGICAL RESPONSES OF EMBRYONIC HEERMANN'S GULLS TO TEMPERATURE ${ }^{1}$
}

\author{
ALBERT F. BENNETT AND WILLIAM R, DAWSON \\ School of Biological Sciences, University of California, Irvine, Califorina 92717; and \\ Division of Biological Sciences, University of Michigan, Ann Arbor, Michigan 48109
}

(Accepted 2/12/79)

Oxygen consumption, heart rate, and thermal tolerance were measured in week-old embryos of Heermann's gull (Larus heermanni). Heart rate and oxygen consumption are temperature independent between 30 and $40 \mathrm{C}$ and average 120 beats/min and $1.87 \mathrm{~cm}^{3} \mathrm{O}_{2} /(\mathrm{egg} \cdot \mathrm{h})$. Below $30 \mathrm{C}$, these rate processes become strongly temperature dependent, and the heart stops beating when cooled to $7-13 \mathrm{C}$. The beat recovers when the embryo is rewarmed, even after $1 \mathrm{~h}$ at $6 \mathrm{C}$. The heart beat stops when the embryo is heated above 40.0-41.6 $\mathrm{C}$ but recovers with cooling. However, the beat does not recover after the embryo has been heated to $43 \mathrm{C}$ for $1 \mathrm{~h}$. The thermal independence of embryonic function over the 30-40 C range minimizes disruptions associated with variation of temperature during incubation. Unattended eggs at night may chill to temperatures which cause cessation of heart beat, but such exposure is not lethal if the eggs are rewarmed. Exposure to radiant heat during the day can rapidly raise egg temperature to levels which kill the embryo. Thus, an important aspect of incubation by adult Heermann's gulls is shading of the eggs and prevention of overheating.

\section{INTRODUCTION}

The avian egg develops under thermal conditions which are strongly influenced by the behavioral activities of the parent or parents. Depending on time of day, interruptions in parental attentiveness introduce risk of chilling or overheating, or, at the very least, variable thermal

(c) 1979 by The University of Chicago.0031-935X/ $79 / 5204-7718 \$ 00.88$
${ }_{1}$ This study was supported in part by NSF grants BMS 75-3300 and DEB 76-7817 to W. R. D. and PCM 75-10100 to A. F. B. We wish especially to thank Dr. Bernardo Villa Ramirez, Instituto de Biologia, Universidad Autonoma de Mexico, for his valuable assistance. The crew of the $\mathrm{R} / \mathrm{V}$ Dolphin (Scripps Institution of Oceanography, University of California, San Diego) was most helpful to our study. We thank the government of Mexico and the Office of the Secretary of External Relations for permission to operate in Mexican territorial waters and collect the eggs used in our study (permit no. 502113, dated 20 March, 1976). 
conditions under which development must proceed. Fluctuation of thermal conditions within the egg would be particularly serious in environments characterized by intense solar radiation and wide daily fluctuations in temperature. Such conditions would place a premium on compensatory mechanisms in the physiology of the embryo that would prevent or minimize disruptions of development. Despite the probable importance of such mechanisms, the limited information available on the physiology of avian embryos is virtually confined to observations on the domestic fowl (Gallus gallus).

The above considerations led us to initiate a coordinated research project dealing with microclimatic conditions, parental behavior, and moisture and thermal relations of embryos of Heermann's gull (Larus heermanni). A major breeding colony of this species uses Isla Rasa, Baja California Norte, Mexico. This desert island located in the Gulf of California receives intense solar radiation during the day and is characterized by relatively wide diurnal fluctuations in ambient temperature. In this report we deal with some of the physiological responses of embryonic Heermann's gulls to temperature. Other physiological and behavioral aspects of this study are published elsewhere (Bartholomew and Dawson 1979; Rahn and Dawson 1979). We measured the influence of temperature on the rates of oxygen consumption and heart beat of gull embryos. Cardiac function was also used to define the thermal tolerance of embryonic Heermann's gulls, since failure of heart action is regarded as the principal cause of death during thermal stress in embryonic domestic fowl (Szarski 1948). All our measurements were made on embryos during the first week of development. Relative growth and development are most rapid during this period (Romanoff, Smith, and Sullivan 1938), which is also characterized by the greatest incidence of embryonic deaths and malformations (Riddle 1930; Romanoff 1949, 1972). Embryos of G. gallus are also more sensitive to high temperatures during this period than later in their development (Romanoff 1934; Romanoff and Sochen 1936; Moreng and Shaffner 1951).

\section{MATERIAL AND METHODS}

Eggs were collected on Isla Rasa on April 16-24, 1976. Embryonic age was estimated in the field by determining the angle at which the egg floated in water: eggs with week-old embryos float at a $45^{\circ}-60^{\circ}$ angle with the horizontal. The eggs were transported to the $\mathrm{R} / \mathrm{V}$ Dolphin within $30 \mathrm{~min}$ of collection and maintained at $20 \mathrm{C}$ until experimentation, which was always within $6 \mathrm{~h}$ of collection. The stage of development of each embryo was later determined by reference to comparable developmental stages of the domestic fowl (Hamburger and Hamilton 1951; Freeman and Vince 1974). The age assigned to each was adjusted proportionately for the slightly longer incubation period of the gull (25 days vs. 21 days for the domestic fowl [Herzig-Zürcher 1978]). The mean age of the embryos utilized was 6.3 days ( $\pm 0.40 \mathrm{SE}$, range $=1.9-8.9$ days $)$.

In experiments examining the thermal dependence of heart rate, embryos with intact chorio-allantoic membranes were dissected from the underlying yolk and were placed in a small plastic dish containing Ringer's solution (145 $\mathrm{mM}$ $\mathrm{NaCl}, 3.4 \mathrm{mM} \mathrm{KCl}, 2.3 \mathrm{mM} \mathrm{CaCl}, 3.0$ $\mathrm{mM} \mathrm{NaHCO} 3$ ). A fine (40-gauge) thermocouple used with a thermocouple meter (SB Systems) was inserted into the embryonic tissue directly adjacent to the heart. The frequency of heart 
beat (atrial or ventricular contractions) was observed with a dissecting microscope and timed with a stopwatch. Embryos were heated above or cooled below room temperature by placing the plastic container on an adjustable electric hot plate or on crushed ice. The temperature of the embryo was changed at $0.2-1.0 \mathrm{C} / \mathrm{min}$ and heart rate monitored until beating ceased at the low or high temperature limit. To determine whether removal of the embryo from the egg had any effect on heart rate at various temperatures, other eggs were opened by removing a circular area of the shell. Heart rate was determined immediately in situ and the temperature of the embryo measured with a thermocouple.

To test the thermal tolerance and viability of embryos in intact eggs, fine thermocouples were inserted about $1 \mathrm{~cm}$ into the albumen compartment. Eggs were equilibrated for $1 \mathrm{~h}$ in a controlled temperature cabinet set at a level between 42 and $45 \mathrm{C}$. A small area of shell was then removed and a few drops of mineral oil were added to slow cooling by evaporation. A thermocouple was inserted close to the heart, which was observed for the persistence and frequency of beating. These were monitored as the egg cooled to room temperature. Cold tolerance of the embryos was determined in a similar manner after equilibration to $6-7 \mathrm{C}$ for $1 \mathrm{~h}$.

Oxygen consumption of intact eggs was determined by closed-circuit respirometry in which gas samples were subjected to paramagnetic oxygen analysis using a Beckman F-3 oxygen analyzer $\left(\begin{array}{lll}20 \% & -21 \% & \mathrm{O}_{2}\end{array}\right)$. Eggs were placed on wire platforms in individual metabolic chambers fashioned from 2-liter paint cans. The volume of the chambers was reduced to 1 liter by the addition of water to the chamber; consequently, relative humidity was $100 \%$. One egg in each series was fitted with a fine thermocouple in its albumen compartment. The metabolic chambers were placed in the thermostated cabinet and the eggs were equilibrated sequentially at $20,30,35$, and $40 \mathrm{C}$. During the equilibration, the chambers were ventilated with air continuously. After equilibration, a sample of excurrent air from which water vapor and carbon dioxide had been absorbed was analyzed for oxygen content. The ports into the chambers were then closed and the egg left at $20 \mathrm{C}$ for $2 \mathrm{~h}$ or, at the higher temperatures, for $1 \mathrm{~h}$. A sample of chamber air was then passed through the oxygen analyzer by adding water slowly to the chamber. Volume of the eggs was calculated from their length and width according to a formula developed for this species by Hoyt (1979), and chamber volume was corrected for egg volume. Oxygen consumption was calculated from the volume of air and the decrement in oxygen partial pressure within the chamber, using an equation modified from those provided by Depocas and Hart (1957) for dry, $\mathrm{CO}_{2}$-free air. All volumes reported are corrected to STPD.

\section{RESULTS}

The frequency of heart beat as a function of temperature is reported in figure 1 for 14 embryos removed from their eggs. The thermal dependence is complex and is best described by the following equation obtained by the method of least squares: $\log y=$ $-0.5996+0.1399 T-0.0018 T^{2}$, when $T=$ temperature in $\mathrm{C}$ between 8 and $41 \mathrm{C}$ and $y=$ heart rate in beats $/ \mathrm{min}$. Above $32.0 \mathrm{C}$, the heart rate is independent of temperature $(P=.32)$, averaging 120 beats $/ \mathrm{min}$. Below this temperature, cooling progressively reduces 


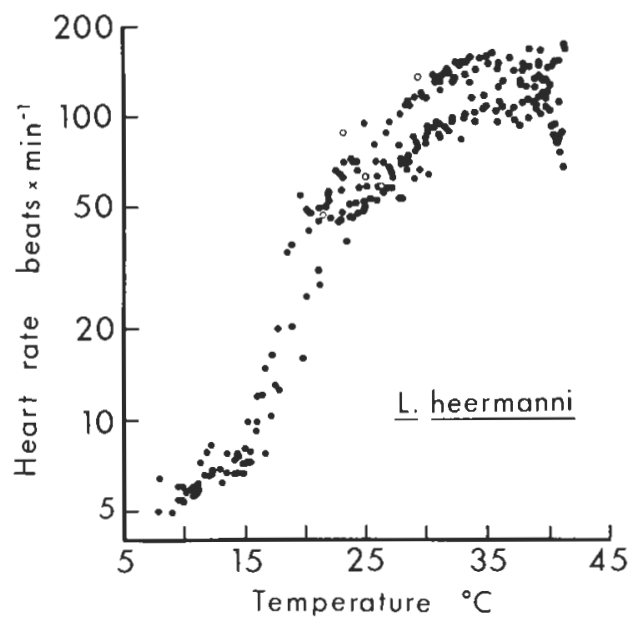

FIG. 1.- Heart rate in week-old embryos of Heermann's gull. Solid circles indicate measurements on 14 excised embryos with intact chorioallantoic membranes; the five open circles are measurements on in situ embryos viewed through a hole in the shell.

the beating frequency until, below $20 \mathrm{C}$, rates fall precipitously to minimum values of approximately 5 beats $/ \mathrm{min}$ just above cold-blocking temperatures. Removal of the embryo from its egg apparently has little effect on heart rate: frequencies for embryos in situ are similar to those of excised embryos (fig. 1).

The hearts beat over a $28-33 \mathrm{C}$ range of temperature. Heat blockage occurs at approximately $41.1 \mathrm{C}$ (no. $=5$; range, $40.0-41.6 \mathrm{C}$ ). The frequency usually decreases with the beating sometimes becoming irregular, about $1 \mathrm{C}$ below blocking temperature. More variability is evident in the lower temperature required to stop the heart: values range from 7.9 to $13.0 \mathrm{C}$ among the four individuals tested.

Exposure to temperatures which block cardiac activity is not necessarily lethal. As shown in table 1, embryos in intact eggs maintained at either $6 \mathrm{C}$ or $42-43 \mathrm{C}$ for $1 \mathrm{~h}$ resumed normal heart rates when returned to room temperature.
TABLE 1

SURVIVAI, OF THERMAL STRESS BY WEEK-OLD EMBRYOS OF HEERMANN'S GULLS ${ }^{\mathrm{a}}$

\begin{tabular}{ccc}
\hline \hline $\begin{array}{c}\text { Temperature } \\
\left({ }^{\circ} \mathrm{C}\right)\end{array}$ & $\begin{array}{c}\text { No. } \\
\text { Exposed }\end{array}$ & $\begin{array}{c}\text { No. } \\
\text { Surviving }\end{array}$ \\
\hline $6 \ldots \ldots \ldots \ldots \ldots$ & 4 & 4 \\
$42-43 \ldots \ldots \ldots \cdots$ & 3 & 3 \\
$43-44 \ldots \ldots \ldots$ & 2 & 0 \\
$44-45 \ldots \ldots \ldots \cdots$ & 2 & 0 \\
\hline
\end{tabular}

a Intact eggs exposed for $1 \mathrm{~h}$.

Embryos did not survive exposure to temperatures above $43 \mathrm{C}$ : cardiac function never resumed in these embryos. The latter is assumed to be the upper lethal temperature for week-old embryos of this species.

Oxygen consumption of embryos within intact eggs at various temperatures is summarized in figure 2. Although metabolic rate varies directly with temperature between 20 and $30 \mathrm{C}\left(\mathrm{Q}_{10}=\right.$ 2.05 ), it remains essentially constant between 30 and $40 \mathrm{C}$, the slope of the curve not differing significantly from zero $(P=.68)$. Oxygen consumption over this range averages $1.87 \mathrm{~cm}^{3} /$ $(\mathrm{egg} \cdot \mathrm{h})$. The mean mass of these embryos (wet and membrane free) was $0.25 \mathrm{~g}$; consequently mass-specific metabolic rate was approximately $7.5 \mathrm{~cm}^{3}$ $\mathrm{O}_{2} /(\mathrm{g} \cdot \mathrm{h})$.

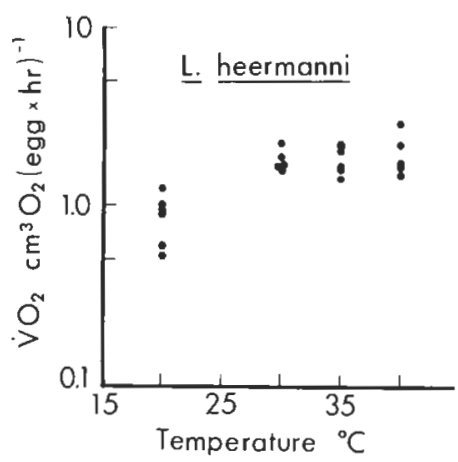

FIG. 2.-Oxygen consumption of intact eggs containing week-old embryos of Heermann's gull. 


\section{DISCUSSION}

Gulls have a predominantly circumpolar and temperate geographic distribution, and cold rather than heat might appear to be the more prevalent form of potential thermal stress for their eggs and young. However, even in temperate areas young gulls may rapidly experience heat stress when left unattended by the parents (Dawson, Hudson, and Hill 1972; Dawson, Bennett, and Hudson 1976). Since the climate of Isla Rasa is dominated by solar radiation, the local breeding colony of Heermann's gulls is subjected to considerable heat stress. Adult gulls engage in vigorous heat defense almost daily while sitting on their nests (Bartholomew and Dawson 1979).

The thermal environment of the embryonic Heermann's gull varies even when the adults are in attendance on the nest. The nests themselves consist of little more than depressions in the dirt ornamented with a few twigs and provide little shelter. Unlike most incubating birds (see White and Kinney 1974), Heermann's gulls permit fluctuation in the temperature of their eggs. Incubated egg temperature during our study period averaged 36.7 C (Bakken, Buttemer, and Dawson, unpublished data). When unprotected by the adults, the eggs undergo wide thermal fluctuations: the temperature of a model egg placed in an unprotected position in a gull nesting area is reported in figure 3 . The mean daily minimum and maximum temperatures of this egg were $12.6 \mathrm{C}$ (range 8.4-16.4 C) and $45.9 \mathrm{C}$ (range $41.0-48.8 \mathrm{C})$, respectively. The egg remained heated above $43.0 \mathrm{C}$ for more than 1 h on 6 out of the 8 days measured. Less thermal lability would probably occur in intact unincubated eggs, owing to their greater thermal inertia. However, the test egg serves to illustrate the potential heat stress on Isla Rasa, for intact eggs left uncovered in the full sun heated from an incubation temperature of $36 \mathrm{C}$ to above $43 \mathrm{C}$ in approximately $15 \mathrm{~min}$.

Our measurements indicate that embryonic Heermann's gulls can be fatally injured by exposure to the diurnal thermal environment in this colony if the eggs are not shaded by an adult gull (see fig. 3). These measurements establish that exposure to $41 \mathrm{C}$ is sufficient to cause the cessation of heart beat in week-old embryos, and exposure to $43 \mathrm{C}$ for $1 \mathrm{~h}$ causes death. This upper thermal limit of embryos of Heermann's gull apparently does not exceed that of other birds which have been examined (see table 2). Heart beat in embryos of the domestic fowl ceases at $40-41 \mathrm{C}$ and recovers if the embryo is returned to $32 \mathrm{C}$; however, heart beat does not recover after embryos are heated to $45 \mathrm{C}$ (Schenk 1867). Exposure of eggs of the house wren (Troglodytes aedon) to $41.1-43.9 \mathrm{C}$ for $1 \mathrm{~h}$ is lethal to half the embryos; $45.6 \mathrm{C}$ for the same period is lethal to all (Baldwin and Kendeigh 1932). Thus, we find no evidence of specific adjustment of upper lethal limits in embryos of this gull in spite of the danger of environmentally induced heat stress.

The upper temperature which causes a cardiac block in these gull embryos is below the body temperatures of adult gulls. Two Heermann's gulls caught in flight during our study had rectal temperatures of 41.2 and $42.3 \mathrm{C}$. Other species of gulls have been found to have temperatures ranging from 40.3 to 42.6 , with most of the values exceeding $41 \mathrm{C}$ (Wetmore 1921; Irving and Krog 1954; Drent 1967). Body temperatures at these levels are injurious to embryos we investigated, and, consequently, the temperatures at which gull eggs are 
incubated must be below the body temperature of the incubating parent. Tolerance of acute heat exposure appears to increase and tolerance of acute cold exposure to decrease during embryonic development of birds (Romanoff 1934, 1960; Romanoff and Sochen 1936; Moreng and Shaffner 1951; MacMullan and Eberhardt 1953; Ancel 1958; Lundy 1969).

At night, the temperature of exposed eggs of Heermann's gulls can fall to levels which block the heart beat of the embryos (see fig. 3). Chronic exposure to cold temperature results in retardation of growth and gross malformations in avian embryos (Ancel 1958; Romanoff 1972). However, the effects of acute exposure to nonfreezing temperatures appear readily reversible upon rewarming. Embryonic domestic fowl at all stages of development survive $1 \mathrm{~h}$ at $0 \mathrm{C}$

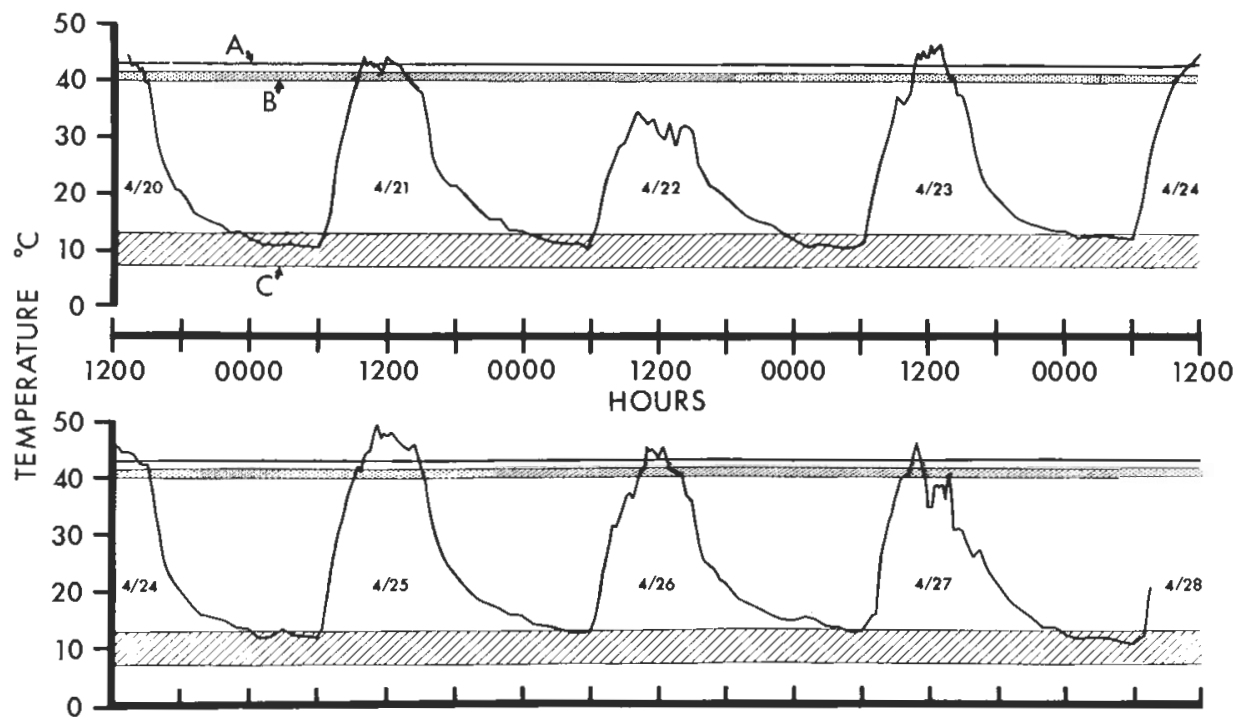

Fig. 3.-Daily temperature record for an unincubated test egg. This egg was obtained from a Heermann's gull nest, the contents were removed, and the inner surface of the shell was coated with copper. It was fitted with a thermocouple and placed near a nest among the rocks on an east-facing slope on Isla Rasa. The egg was unshaded throughout all but the last part of the day. Line $A$ marks the upper lethal temperature established in the present study for Heermann's gull embryos near the end of the first week of development. Bands $B$ and $C$ mark the respective temperature ranges in which heat and cold suppression of heart rate occurred in these embryos.

TABLE 2

HIGH TEMPERATURES CAUSING CESSATION OF HEART BEAT IN AVIAN EMBRYOS DURING FIRST WEEK OF DEVELOPMENT

\begin{tabular}{|c|c|c|}
\hline Species & $\begin{array}{l}\text { Temperature } \\
\left({ }^{\circ} \mathrm{C}\right)\end{array}$ & Reference \\
\hline Domestic fowl. . & $40-41$ & Schenk 1867 \\
\hline Domestic fowl. . . . . & $42-43$ & Cesana 1911-1912 \\
\hline Domestic fowl. & 46.5 & Romanoff and Sochen 1936 \\
\hline Domestic fowl. & $41-44$ & Moreng and Shaffner 1951 \\
\hline Duck.......... & 43 & Inukai 1925 \\
\hline Heermann's gull . . . . & $40.0-41.6$ & This study \\
\hline
\end{tabular}


(Moreng and Shaffner 1951), and some eggs of Manx shearwaters (Puffinus puffinus) maintained at $17 \mathrm{C}$ for several days ultimately hatched following rewarming (Matthews 1954). Several Russian workers have even reported improved hatching success with clutches of fowl eggs subjected to periodic chilling in comparison with eggs maintained at constant high incubation temperatures (see Lundy 1969 for references). Cold, therefore, appears to present a less serious threat than heat to the gull embryos on Isla Rasa. A gull egg exposed at night may be chilled and have the growth of its embryo slightly retarded; however, an egg exposed during the day can be killed rapidly by overheating in the sun.

In face of the broad range of temperatures occurring during incubation, the week-old gull embryos have an impressive independence of functional capacity. Metabolism and heart rate (and, by inference, delivery of nutrients to growing tissue) are essentially constant upon acute exposure to temperatures between 30 and $40 \mathrm{C}$. This constancy in these important physiological variables suggests that considerable fluctuation can be tolerated in incubation temperature without disrupting development. The mechanisms leading to stabilization of the rates with which we are concerned are unknown.

It is difficult to determine whether rate processes of other avian embryos show a similar thermal independence in the range of temperature associated with incubation. Surprisingly few data exist on the response of metabolic rate of avian embryos to acute temperature exposure. The only data obtained for embryonic domestic fowl under wellcontrolled, acute experimental conditions do indicate a low thermal dependence of oxygen consumption $\left(\mathrm{Q}_{10}=\right.$ 1.6 for 15-38 C [Hasselbalch 1900]; $\mathrm{Q}_{10}=1.0$ for 34-40 C [Greiff 1952]). Heart rates in embryos of ducks and domestic fowl show a decreasing thermal dependence with increasing temperature, ranging from $Q_{10}$ 's in excess of 4.0 at 20-25 C to $1.4-1.9$ at 35-40 C (Inukai 1925; Parpart and Glaser 1930; Paff et al. 1963 ; see table 3 ). Thermal dependence of heart rate generally decreases with increasing age of the embryo (Murray 1926; Cohn 1928; Romanoff and Sochen 1936). A clear indication exists in all these examples of a lower thermal dependence than anticipated for most biological reactions, for which $Q_{10}$ typically lies between 2 and 3 (table 3). However, none of the reported $\mathrm{Q}_{10}$ values between 30 and $40 \mathrm{C}$ is as low as those measured for Heermann's gulls. We are intrigued at the indications that some fluctuation in incubation temperature is permissible without producing major physiological disruptions. The adaptive significance of this ap-

TABLE 3

$Q_{10}$ VALUES FOR HEART RATE OF AVIAN EMBRYOS

\begin{tabular}{|c|c|c|c|c|}
\hline Species & $\begin{array}{c}\text { Age } \\
\text { (Days) }\end{array}$ & $\begin{array}{c}\text { Temp. Range } \\
\left({ }^{\circ} \mathrm{C}\right)\end{array}$ & $Q_{10}$ & Reference \\
\hline Domestic fowl. . & $2-8$ & $30-40$ & 1.7 & Cesana 1911-1912 \\
\hline Domestic fowl. & 6 & $33-39$ & 1.8 & Cohn 1928 \\
\hline Domestic fowl. & 7 & $35-40$ & 1.5 & Parpart and Glaser 1930 \\
\hline Domestic fowl. . & 3 & $35-40$ & 1.6 & Paff et al. 1963 \\
\hline Domestic fowl. . & 7 & $31.5-40.5$ & 1.4 & Romanoff and Sochen 1936 \\
\hline Duck. . . . . . . . & 3 & $35-40$ & 1.9 & Inukai 1925 \\
\hline Heermann's gull. & $2-9$ & $35-40$ & 1.1 & This study \\
\hline
\end{tabular}


parent thermal insensitivity is readily apparent for Heermann's gulls; the situation in other species of wild birds remains to be determined.

The role of attentiveness of parent gulls in regard to the developing egg has generally been defined in terms of providing incubation and protection from other gulls. However, shading the eggs from solar radiation may be even more important in environments such as that on Isla Rasa. This duty can impose severe heat stress on the parent bird. The more commonly identified thermal benefit of attentiveness, keeping the eggs warm, is also of importance on Isla Rasa. However, some protection against thermal fluctuations in the egg is provided by the considerable range in incubation temperature that appears tolerable. Exposure of the egg to a cool environment is never lethal, although it might retard development. Heat death is a more immediate threat to successful reproduction.

\section{LITERATURE CITED}

ANCEL, P. 1958. Recherches sur l'action tératogène du refroidissement temporaire de l'oeuf de Poule au cours de l'incubation. J. Embryol. Exp. Morphol. 6:335-345.

Baldwin, S. P., and S. C. Kendeigh. 1932. Physiology of the temperature of birds. Cleveland Mus. Natur. Hist. Sci. Pub. 3. 196 pp.

Bartholomew, G. A., and W. R. Dawson. 1979. Thermoregulatory behavior during incubation in Heermann's gulls. Physiol. Zool. 52 : 422-437.

Cesana, G. 1911-1912. Intorno al coefficiente termico del cuore embrionale di pollo nei primi giorni dello sviluppo. Arch. Fisiol. 10:193-204.

Conn, A. E. 1928. Physiology ontogeny. A. Chicken embryos. XIII. The temperature characteristic for the contraction rate of the whole heart. J. Gen. Physioi. 11:369-375.

Dawson, W. R., A. F. Bennet, and J. W. Hudson. 1976. Metabolism and thermoregulation in hatchling Ring-billed Gulls. Condor 78:49-60.

Dawson, W. R., J. W. Hudson, and R. W. Hill. 1972. Temperature regulation in newly hatched Laughing Gulls (Larus alricilla). Condor 74: 177-184.

Depocas, F., and J. S. HaRT. 1957. Use of the Pauling oxygen analyzer for measurement of oxygen consumption of animals in open-circuit systems and in a short-lag, closed circuit apparatus. J. Appl. Physiol. 10:388-392.

Drent, R. H. 1967. Functional aspects of incubation in the herring gull (Larus argentatus Pont). Ph.D. thesis. University of Groningen.

Freeman, B. M., and M. A. Vince. 1974. Development of the avian embryo. Chapman \& Hall, London.

GreIFF, D. 1952. The metabolic interactions of intracellular parasites and embryonate eggs. Ann. New York Acad. Sci. 55 :254-266.

Hamburger, V., and H. L. Hamilton. 1951. A series of normal stages in the development of the chick embryo. J. Morphol, 88:49-92.
Hasselibalch, K. A. 1900. Ueber den respiratorischen Stoffwechsel des Hühnerembryos. Skand. Arch. Physiol. 10:353-402.

HERZIG-ZürCHER, M. S. 1978. Contribucion al conocimiento de la histogenesis de las glandulas supra orbitales en Larus heermanni (Cassin). Tesis Profesional, Facultad de Ciencias, Universidad Nacional Autonoma, Mexico.

Hoyt, D. F. 1979. Practical methods of estimating volume and fresh weight of bird eggs. Auk 96: 73-77.

InUkAI, T. 1925. Über den Einfluss der Temperature auf die Pulsationszahl bei den Amphibienlarven und Vogelembryonen. Jap. J. Zool. 1: 67-75.

IRving, L., and J. KROG. 1954. Body temperature of arctic and subarctic birds and mammals. J. Appl. Physiol. 6:667-680.

LunDY, H. 1969. A review of the effects of temperature, humidity, turning and gaseous environment in the incubator on the hatchability of the hen's egg. Pages 143-176 in T. C. CARTER and B. M. Freeman, eds., The fertility and hatchability of the hen's egg. Oliver \& Boyd, Edinburgh.

MacMullan, R. A., and L. L. Eberhardt. 1953. Tolerance of incubating pheasant eggs to exposure. J. Wildlife Manage. 17:322-330.

Matrhews, G. V. T. 1954. Some aspects of incubation in the Manx shearwater Procellaria puffinus, with particular reference to chilling resistance in the embryo. Ibis $96: 432-440$.

Moreng, R. A., and C. S. Shaffner. 1951. Lethal internal temperatures for the chicken, from fertile egg to mature bird. Poultry Sci. 30:255-266.

Murray, H. A., JR. 1926. Physiological ontogeny. A. Chicken embryos. $X$. The temperature characteristic for the contraction rate of isolated fragments of embryonic heart muscle. J. Gen. Physiol. 9:781-788.

Paff, G. H., R. J. Boucek, R. E. Nieman, and 
W. B. Deichmann. 1963. The embryonic heart subjected to radar. Anat. Rec. 147:379-385.

Parpart, E. R., and O. Glaser. 1930. Temperature and heart rate in chick embryos. J. Exp. Biol. $7: 143-153$.

RAHN, H., and W. R. DAwson. 1979. Incubation water loss in eggs of Heermann's and Western gulls. Physiol. Zool. 52:451-460.

RidDLE, O. 1930. Studies on the physiology of reproduction in birds. XXVII. The age distribution of mortality in bird embryos and its probable significance. Amer. J. Physiol. 94:535-547.

RoMANOFF, A. L. 1934. Study of artificial incubation of game birds. Cornell Univ. Agric. Exp. Sta. Bull. 616.

-.. 1949. Critical periods and causes of death in avian embryonic development. Auk 66:264270.

- 1960. The avian embryo. Macmillan, New York.

—_ 1972. Pathogenesis of the avian embryo.
Wiley-Interscience, New York.

Romanoff, A. L., L. C. Smith, and R. A. Sullivan. 1938. Biochemistry and biophysics of the developing hen's egg. III. Influence of temperature. Cornell Univ. Agric. Exp. Sta. Mem. 216.

Romanoff, A. L., and M. Sochen. 1936. Thermal effect of the rate and duration of the embryonic heart beat of Gallus domesticus. Anat. Rec. 65: 59-68.

Schenk, S. 1867. Zur Physiologie des embryonalen Herzens. Sitzungber. Akad. Wiss. Wien Math.Naturw. Kl. 56:111-115.

SzARSKI, H. 1948. On the thermal death of the chicken embryo. Pol. Akad. Umiejet. Krakow. Wydzial. Math. Bull. Internat. Ser. B, Sci. Natur. 7-10:133-144.

WeTMORE, A. 1921. A study of the body temperature of birds. Smithsonian Misc. Collection 72: $1-52$.

White, F. N., and J. L. Kinney. 1974. Avian incubation. Science 186:107-115. 